\title{
Universality challenge
}

W e face vicious public spending cuts. Haldane members have a particular responsibility to defend the legal aid budget. But we also have a duty, as citizens and consumers of public services, to fight the cuts to the NHS, to education including the rise in tuition fees, to welfare benefits and other public services including social housing.

These cuts target the poor. Potential university students from poorer families will be deterred from pursuing higher education by the prospect of lifelong debt. Housing benefit cuts condemn tenants in both private and social rented housing to moving ceaselessly from one unaffordable property to another, and to move from their neighbourhoods to areas providing cheaper accommodation. Court closures restrict access to justice, as litigants have to travel further and more public sector jobs are lost.

Proposals to give new council and housing association tenants 'flexible tenancies' - limited to two years, renewable only if the tenant remains unemployed and in desperate need - trap those tenants into poverty and dependence on welfare benefits. There is little incentive to look for a job if you will lose your home as a result. The supply and quality of social housing has been massively depleted by 30 years of the 'right to buy' and lack of public investment. These proposals will ghettoise social housing as a safety-net of last resource, only to be provided to the most desperate and inevitably at a low standard.

Despite David Cameron's statements during the election, the $\mathrm{NHS}$ is not protected from cuts. NHS staff, like other public sector workers, are all subject to a two year wage freeze - a wages cut in real terms. Lansley's pathfinder GP consortia - commissioning treatment for their patients from hospitals - will mean that decisions on treatment are dictated by cost, not what is best for the patient. GPs don't want that. For all its inadequacies, the NHS is a glorious achievement, not least because treatment is determined by patient need. Its public nature needs defending against increasing privatisation.

The Government's Green Paper Prooposals for the Reform of Legal Aid in England and Wales proposes cuts of $£ 350$

음 million from the legal aid budget of $£ 2.1$ bil-

lion. The cuts fall in the area of social welfare

law and civil claims - where people are enforc-

흘 ing their rights. Legal aid will not be available for

产 private law family disputes unless domestic vi-

o olence or child abduction issues are relevant.

T. There will be no legal aid for housing damages claims,

clinical negligence, consumer protection, criminal in-

$\frac{.0}{\square}$ juries compensation, debt, disputes over education, em- ployment cases, welfare benefits and immigration claims (excluding asylum). Financial eligibility is slashed. So far fewer than the current 29 percent of the population could claim legal aid even when it is available. A 10 percent cut in rates, frozen over five years, might mean the end of specialist legal aid providers who can no longer make ends meet and meet their office costs. Even if legal aid remains available, there may no legal aid providers. As our friends in Young Legal Aid Lawyers put it, only the rich and the near destitute will have access to justice.

With Young Legal Aid Lawyers, The Haldane Society is holding a Commission of Inquiry into the Case for Legal Aid in Parliament on 2nd February 2011, providing testimony from those who have benefited from legal aid. Please contact us if you can help. We should all be responding to the Green Paper - consultation closes on 14th February 2011. We support Justice For All, Save Legal Aid and the other campaigns to keep legal aid and advice.

We are inspired by the resistance of students and higher education staff. Haldane members have been on demonstrations and are providing legal representation about kettling, student occupations and criminal charges. The students and lecturers are leading the way and we hope that public sector workers will join them in resistance. We support the TUC Day of Action to Stop the Cuts on Saturday 26th March 2011. Lawyers are public sector workers too. We will be on the Day of Action with the Haldane banner and hope members will march with us.

We will work with different groups opposing the cuts such as the Coalition of Resistance, the Right to Work campaign and with the trade unions. If the ConDems get away with these punitive cuts, we face a return to levels of poverty and social inequality last seen in the 1930s.

The 1945 Labour Government built the welfare state - whilst holding down a deficit of 100 percent. The great genius of the welfare state is its universality. We are all entitled to free education, free health treatment, certain welfare benefits. That universality results in a more cohesive, collective society. We are all in it together. Sit in any $\mathrm{NHS}$ waiting room and you see how diverse patients are.

Over the last 30 years, that universality has been whittled away. We have been encouraged to buy our way out of public services and buy private education, private health insurance, use our homes as commodities. So it is the poor who are more dependent on public services. The Con-Dems want public services to be only for the poor - provided as a minimum and substandard safety-net or simply not available at all. If we don't stand up and fight now, it will be too late.

- Liz Davies, chair of the Haldane Society of Socialist Lawyers

lizdavies@riseup.net 